TẠP CHÍ KHOA HỌC ĐẠI HỌC TÂN TRÀO
ISSN: $2354-1431$

\title{
Nguyễn Ái Quốc - Hồ Chí Minh và văn học Pháp
}

\author{
Nguyễn Thanh Tú ${ }^{a *}$, Đinh Thanh Hưong ${ }^{b}$ \\ ${ }^{a}$ Tạp chi Văn nghệ Quân đội \\ ${ }^{b}$ Truòng Cao đẳng Su phạm Điện Biên \\ "Email:Thanhhaiha2005@yahoo.com.vn
}

\section{Thông tin bài viết}

Ngày nhận bài:

06/5/2018

Ngày duyệt đăng:

$12 / 6 / 2018$

\section{Tù khoá:}

Văn hóa, văn học dân gian, văn học hiện đại, biểu trung.

\section{Tóm tắt}

Bài viết tìm hiểu tác giả tiếp thu, vận dụng văn học Pháp ở ba phương diện: văn học dân gian, văn học hiện đại và các biểu trưng, khái niệm văn hóa, văn học. Tiếp thu, học tập, kế thừa tinh hoa văn học Pháp đã góp phần tạo ra một phong cách văn chương Hồ Chí Minh đa dạng, độc đáo, đặc sắc, tinh tế. Đây là mẫu mực cho ngày hôm nay: trước hết phải có một tấm lòng yêu đất nước mình, yêu con người sâu sắc mới có thể tiếp thu một cách trọn vẹn và hữu ích nhất văn hóa nước ngoài.
Với quan niệm tất cả vì mục đích "tự do cho đồng bào tôi, độc lập cho Tổ quốc tôi" nên khi còn hoạt động ở nước ngoài, đặc biệt là trên đất Pháp, Nguyễn Ái Quốc - Hồ Chí Minh rất có ý thức tiếp thu văn hóa nước ngoài, lấy đó là một thứ vũ khí đấu tranh sắc bén chống chủ nghĩa thực dân, đòi quyền tự quyết, quyền sống cho các dân tộc bị áp bức. Với tư cách là một người viết tác giả cũng rất chú ý tới việc giới thiệu, quảng bá văn hóa Việt với thế giới. Ở ngày hôm nay khi mà xu thế toàn cầu hóa đang diễn ra mạnh mẽ, đứng trên quan điểm tiếp biến văn hóa càng thấy rõ tư tưởng này đi trước thời đại. Việc làm chủ ngôn ngữ, am hiểu văn hóa Pháp như một phương tiện hiệu quả đã góp phần giúp Người sáng tạo những kiệt tác văn chương thể hiện khát vọng giải phóng con người, giải phóng đất nước. Nguyễn Ái Quốc - Hồ Chí Minh là một trong những người sớm nhất đóng vai trò sứ giả gắn nối hai nền văn hóa Việt-Pháp.

Trong những năm đầu viết báo, trong nguyên bản tiếng Pháp tác giả vẫn viết bằng chữ Việt những danh từ chỉ người Việt như con gái, quan lớn, lính lệ, nhà quê. Trên báo Le Paria số 4, ngày 1-7-1922, trong bài báo Thù ghét chủng tộc tác giả dùng hai chữ "con gái" bằng tiếng Việt. Trên báo L'Humanité ngày 17-81922, trong bài Duoói sụ bảo hộ của... các chữ "nhà quê", "Quan lớn", "lính lệ" viết bằng tiếng Việt. Trong truyện Vi hành chữ "dân" viết bằng tiếng Việt. Đặc biệt hai chữ "nhà quê" đều viết bằng tiếng Việt trong tất cả các văn bản tiếng Pháp. Không phải là trong tiếng Pháp không có từ tương ứng mà tác giả có dụng ý hẳn hoi. Người Pháp ở An Nam nuôi những thiếu nữ người Việt vừa để hầu hạ vừa làm trò chơi và gọi những người này bằng âm tiếng Việt - con gái. Do vậy dùng chữ này là một cách tố cáo sự bất bình đẳng ở An Nam với thế giới. Hai chữ "nhà quê" thì mang sắc thái biểu cảm thật rõ, là tấm lòng hướng về người nông dân Việt, về quê hương Việt Nam với bao trân trọng, yêu thương, là sự xót xa vì "nhà quê" ta còn đang trong vòng nô lệ... Ngay cách dùng chữ cũng cho thấy Bác Hồ ngay từ thời còn trẻ đã luôn đau đáu một tấm lòng vì dân vì nước. Có thể thêm một mục đích khác là bước đầu giới thiệu văn hóa Việt (trước hết là ngôn ngữ). Trong truyện Đồng tâm nhất trí (báo L'Humanité, 29/12/1922) có bài ca dao Con mèo mà trèo cây cau được viết bằng tiếng Việt và dịch sang tiếng Pháp. Ở bản tiếng Việt tác giả in hoa chữ cuối câu $l u c$ cùng chữ thứ sáu và thứ tám câu bát như một cách giới thiệu vần cơ bản của thể thơ này. Bác Hồ cũng lại là một trong những người đầu tiên quảng bá văn hoá Việt ra nước ngoài! 
Như vậy, từ góc độ ngôn ngữ cũng cho thấy tác giả có dụng ý văn hóa và chính trị rất rõ ràng. Dưới đây xin tìm hiểu Nguyễn Ái Quốc - Hồ Chí Minh tiếp thu, vận dụng văn học Pháp ở ba phương diện: văn học dân gian, văn học hiện đại và các biểu trưng, khái niệm văn hóa, văn học.

1. Trên báo L'Humanité ngày 30 và $31-5-1922$ có đăng bài báo Pari với lời tựa Trích "Những bức thư gửi cô em họ" do tác giả dịch tù tiếng An Nam. Với phong cách thân mật hoá, người gửi thư kể cho cô em họ biết về một Pari bên cạnh cái vẻ sang trọng là những cảnh nghèo hèn thảm hại. Cách kể "cổ tích" theo trật tự tuyến tính, chậm rãi và xây dựng hình tượng "mụ phù thuỷ” là nét đặc trưng của truyện này. Tác giả mượn hình tượng con mụ phù thuỷ già "lôi thôi và gầy guộc" trong văn học dân gian Pháp để so sánh với Pari thời hiện đại để làm bật ra cái xấu xí, già nua, còm cõi của một khu phố nghèo.

Trong Thu trả lời ông $H$ (Thượng Huyền), viết ngày 9-4-1925 với bút danh L.T, Nguyễn Ái Quốc lấy một câu tục ngữ Pháp để làm rõ quan niệm của mình về tác phẩm văn chương: "Một câu tục ngữ Pháp có nói: "Bơ nhiều hơn là bánh mì". Tôi nghĩ rằng một tác phẩm văn chương không cứ dài mới hay". ${ }^{1}$ Ý của câu tục ngữ Pháp thật hay: cái lõi bản chất mới làm nên giá trị sự vật. Tác phẩm văn chương, trong lúc Tổ quốc lâm nguy thì cần sự thiết thực hơn là bóng bẩy. Quan niệm về tác phẩm văn học này hoàn toàn nhất quán với quan niệm sau này của Hồ Chí Minh: Văn hoá cũng là một mặt trận. Nhà văn là chiến sỹ trên mặt trận ấy. Điều ấy cho thấy một trong những khía cạnh biểu hiện bản lĩnh Hồ Chí Minh là sự nhất quán về quan niệm trong suốt cuộc đời!

Ngày 25-7-1947, Chủ tịch Hồ Chí Minh có Thu gưi nhân dân Pháp sau cuộc hội kiến với Pôn Muýt, đại diện Cao uỷ Pháp Bôlae, có đoạn: “...chúng tôi lấy câu châm ngôn hiên ngang của các bạn làm châm ngôn của chúng tôi: "Thà chết không làm nô lệ". Chúng tôi chiến đấu vì công lý. Chúng tôi sẽ tồn tại; chúng tôi sẽ chiến thắng"2. Câu châm ngôn Pháp nổi tiếng thế giới được sử dụng thật đúng với hoàn cảnh Việt Nam đã cố gắng để tránh một cuộc chiến tranh,

\footnotetext{
${ }^{1}$ Hồ Chí Minh toàn tập (2011), Nxb Chính trị Quốc gia - Sự thật, tập 2, tr 170 .

${ }^{2}$ Hồ Chi Minh toàn tập (2011), Nxb Chính trị Quốc gia - Sự thật, tập 5, tr 155 ;
}

nhưng bọn thực dân Pháp thì không muốn thế, bởi chúng quyết tâm chiếm lại nước ta. Đây là lá thư gửi nhân dân Pháp, mục đích là để cho nhân dân Pháp hiểu tình hình, hiểu người Việt Nam không muốn đổ máu, nhưng vì lòng tự trọng nên người Việt quyết không chịu hèn mất nước

Cũng với tinh thần ấy, nhân kỷ niệm ba năm ngày toàn quốc kháng chiến, Chủ tịch Hồ Chí Minh có Điện gưi nhân dân Pháp nhân: "Dân tộc chúng tôi đã chiến đấu "không chút sờn lòng, không điều ân hận", vì chúng tôi chiến đấu cho tự do, cho độc lập, và đối với nhân dân Pháp chúng tôi không thù hằn gì”. ${ }^{3}$ Một câu châm ngôn nổi tiếng của hiệp sỹ Bayard thời trung cổ nước Pháp: "không chút sờn lòng, không điều ân hận". Câu trích có ẩn ý: nếu hiệp sỹ Bayard ngày xưa chiến đấu vì chân lý, công lý, thì chúng tôi nay cũng vậy, chúng tôi phải chiến đấu cho tự do, cho độc lập nên quyết tâm của chúng tôi và hiệp sỹ của nhân dân Pháp là giống nhau. Hãy coi chúng tôi như là những hiệp sỹ Bayard của nước Pháp đang chiến đấu vì lý tưởng, vì “chân lý, công lý”.

Năm 1929 Bác Hồ từ châu Âu về nước Xiêm phát triển tổ chức Việt Kiều gây dựng cơ sở cách mạng. Bác kể cho một đồng chí câu chuyện ngụ ngôn Pháp Trẻ con không nên nghe trộm. Chuyện rằng: Có hai em bé mải chơi bị lạc được một ông cụ đưa về nhà. "Đến đêm, cụ ông bàn với cụ bà làm thịt gà để ngày mai thết hai em bé. Cụ ông nói: “Thịt con lớn hay con bé?". Cụ bà bảo: "Nói khẽ chứ! Nói to, chúng nghe, chúng chạy mất...". Hai em bé được bữa lo sốt vó. ${ }^{4}$ Tưởng chỉ là câu chuyện vui nhưng lại là một bài học chính trị về nhận định con người để gây dựng cơ sở cách mạng, mà như lời bình luận của Bác, có những người "có thái độ bề ngoài tuy thô lỗ như cục sắt nhưng bên trong lại là một tấm lòng vàng”. Những câu chuyện ngụ ngôn mà Bác kể như truyện trên, sinh động và thuyết phục hơn nhiều những bài học lý thuyết chay về mối quan hệ giữa hiện tượng và bản chất, giữa hình thức và nội dung... trong việc nhận xét cá nhân, xây dựng tổ chức cách mạng.

Ngụ ngôn Pháp hay xuất hiện hình tượng con chó, chó sói được tác giả sử dụng nhằm mục đích nghệ thuật riêng: "Trái lại, giống nhu con chó trong chuyện

\footnotetext{
${ }^{3}$ Hồ Chí Minh toàn tập (2011), Nxb Chính trị Quốc gia - Sự thật, tập 5, tr 655;

${ }^{4}$ Nhiều tác giả (1970), Bác Hồ kính yêu, Nxb Kim Đồng, tr 31;
} 
ngụ ngôn, họ lại thích đeo cái vòng cổ để kiếm miếng xương của chủ”. ${ }^{5}$ Một sự phê phán đích đáng tâm lý nô lệ thảm hại ở những người dân bản xứ, vì ít học nên dốt nát, muốn giải phóng nhưng không có phương pháp nên đành chấp nhận sống trong u mê như kiếp chó vậy. Một so sánh vật hoá nhưng ý nghĩa thì vượt lên mang tầm thức tỉnh nhân dân các nước thuộc địa: phải biết tìm ra con đường giải phóng dân tộc!

"Bị thua to và sa lầy ở miền Nam, chúng muốn mở rộng chiến tranh đến miền Bắc hòng gỡ thế bí. Như thế khác nào con chó sói hai chân sau đã bị kẹt vào cạm bẫy, muốn thò cả hai chân trước vào cạm bẫy nữa để giải thoát cho hai chân sau!". ${ }^{6}$ So sánh này không chỉ đúng với tính cách mà còn đúng với cả hoàn cảnh giữa cái so sánh và cái được so sánh. So sánh bọn xâm lược Mỹ với chó sói là chính xác về bản chất: hống hách, hung dữ, hiểm độc, sã̃n sàng ăn thịt cả đồng loại... Đồng thời mỉa mai cay độc về tình cảnh của đế quốc Mỹ lúc này: "đã điên cuồng lại thêm ngu ngốc, luống cuống". Không thể tìm ra một ví dụ nào diễn đạt đúng hơn hoàn cảnh của đế quốc Mỹ như ngụ ngôn này: "khác nào con chó sói hai chân sau đã bị kẹt vào cạm bẫy, muốn thò cả hai chân trước vào cạm bẫy nữa để giải thoát cho hai chân sau!".

2. Nguyễn Ái Quốc - Hồ Chí Minh đặc biệt ưa thích ngụ ngôn La Fontaine nổi tiếng thế giới với những câu chuyện đậm tính chất triết lý, ý nghĩa giáo dục cao đã trở thành cổ điển. Tác giả mượn những ngụ ngôn này vào mục đích cách mạng, tinh tế, hóm hỉnh và hiệu quả. Trong Thu trả lời ông $H$ (Thượng Huyền) Nguyễn Ái Quốc đã lấy ngụ ngôn La Fontaine để mỉa mai "những con chuột An Nam" đớn hèn: "Những người tự hào là dòng giống Rồng Tiên lại không bằng chuột! Thật là hổ thẹn...!"? Truyện ngụ ngôn dã thành một thứ vũ khí cách mạng, để phê phán, tố cáo kẻ thù, để cảnh tỉnh, thức tỉnh người nô lệ, kêu gọi dân ta đoàn kết, để giải thích tình hình...Trong bài Trả lờ ông Vaxiđép Rao, thông tín viên hãng Roito, tác giả mượn ngụ ngôn để vạch trần một cách đích đáng luận điệu xảo trá của thực dân Pháp khi tìm cách cướp nước ta lần nữa: "Nước Việt Nam không có lợi gì gây

${ }^{5}$ Hồ Chí Minh toàn tập (2011), Nxb Chính trị Quốc gia - Sự thật, tập1, tr 81 .

${ }^{6}$ Hò̀ Chí Minh toàn tập (2011), Nxb Chính trị Quốc gia - Sự thật, tập 14, tr 501.

${ }^{7}$ Hồ Chi Minh toàn tập (2011), Nxb Chính trị Quốc gia - Sự thật, tập 2, tr 176,177. chiến tranh để làm cho nhân dân thiệt hại và chịu bao nhiêu tang tóc. Ông hãy nhớ lại bài ngụ ngôn của Lã Phụng Tiên Con chó sói và con cùu". ${ }^{8}$

Truyện Con chó sói và con cùu kể một chú sói làm đục dòng suối, con cừu ra suối uống nước liền bị sói mắng là đã làm bẩn nước, cừu cãi lại, nói chính sói mới là kẻ gây ra. Chó sói liền đòi ăn thịt cừu. Ngụ ý của câu chuyện thật dễ hiểu: liệu cái lý của kẻ mạnh mà độc ác (như sói) bao giờ cũng đúng? Không phải. Kẻ mạnh mà độc ác luôn đi ngược lại chân lý thông thường. Mượn một câu chuyện mà nói được bản chất vấn đề: Pháp như con sói kia, là kẻ đi xâm lược, gây ra chiến tranh mà còn vu cho người Việt "gây ra cuộc xung đột...”. Không có cách diễn đạt nào chính xác hơn, hay hơn cách mượn những ngụ ngôn này. Thật thâm thúy và hài hước khi tác giả lấy chính tác phẩm yêu thích của người Pháp nói chung để mỉa mai, giễu nhại những người Pháp xấu - những kẻ thực dân.

"Lại cũng phải nhận rằng các nhà đi khai hoá của chúng ta đã không từ một sự cố gắng nào để cắm cho mấy con chim sẻ bản xứ - rất dễ bảo và rất ngoan ngoãn - vài cái lông công làm cho chúng trở thành những con vẹt hay những con chó giữ nhà. Và nếu nhân dân châu Phi và châu Á mà được "hoà bình" và "thịnh vượng" đến như thế này, thì chính những "vị đi gieo rắc dân chư" không biết mỏi mệt đó là con nhặng đánh xe chứ còn ai vào đó nữa?.. ${ }^{9}$ Con nhặng đánh xe (la mouche du coche), tức câu chuyện con nhặng trong ngụ ngôn La Phôngten tự khoe mình đã có công đẩy chiếc xe nặng vượt lên con dốc. Nguyễn Ái Quốc mượn câu chuyện này để mỉa mai những kẻ đi khai hoá thuộc địa cũng chẳng khác gì loài nhặng ấy. Cái xe "dân chủ" châu Phi châu Á phải tự nhân dân ở đó kéo lên dốc chứ đâu cần (và cũng không thể là) những “con nhặng” các nhà khai hoá!

"Trong khi ở mẫu quốc có một vụ âm mưu bônsêvích nổi tiếng thì ở Đông Dương các ngài thực dân cũng muốn có một vụ âm mưu tương tự và... cuối cùng các ngài ấy cũng nặn ra một vụ âm mưu thật sự, chẳng khác nào như trong câu chuyện ngụ ngôn con

\footnotetext{
${ }^{8}$ Hồ Chí Minh toàn tập (2011), Nxb Chính trị Quốc gia - Sự thật, tập 5, tr 160,161.

${ }^{9}$ Hồ Chí Minh toàn tập (2011), Nxb Chính trị Quốc gia - Sự thật, tập1, tr 162 .
} 
nhái muốn phình to bụng nhu con bò" ${ }^{10}$ Một ngụ ngôn của La Fontaine: con nhái nhìn thấy con bò to hơn mình liền cố sức phình bụng để cũng to bằng con bò, rốt cuộc nhái vỡ bụng mà chết. So sánh "một vụ âm mưu" với câu chuyện ngụ ngôn nhưng người đọc sẽ hiểu ngay kết cục của nó: câu chuyện bịa đặt âm mưu "bônsêvích" nọ cũng như con nhái vỡ bụng kia, tức là vì không có sự thật, dựa vào ảo tưởng nên thất bại, lại để cho mọi người chê cười.

Là một trong những người Việt Nam sớm tiếp xúc với văn học phương Tây, nhất là văn học Pháp, Nguyễn Sinh Cung khi mới 11, 12 tuổi đã đọc Nhũng kẻ khốn nạn của Víchto Huygô (1802-1885), nhà văn Pháp nổi tiếng với những tác phẩm mang tính nhân đạo sâu sắc, bênh vực con người, tố cáo những bất công. Sau này khi sang Pháp, Nguyễn Ái Quốc tìm hiểu kỹ về nhà văn này. Trong Thu ngỏ gưi ông Lêông Ácsimbô, có đoạn: "Thưa ông Ácsimbô, trong lúc đợi cho ông có "một chức tước hiển vinh nhất mà người ta có thể mơ ước đến" thì tôi xin phép nói rằng, nếu trước kia Víchto Huygô biết là hiện nay ông viết ra những điều như thế trên tờ báo của ông ta, thì ông ta đã không sáng lập ra nó". 11

Tờ báo mà Nguyễn Ái Quốc nói ở đây là tờ $L e$ Rappel xuất bản hằng ngày ở Pari có khuynh hướng chống Giáo hội bênh vực dân nghèo, do Víchto Huygô sáng lập từ 1869 hoạt động đến 1933. Chỉ một chi tiết nhỏ này cũng cho thấy Nguyễn Ái Quốc hiểu biết tường tận báo chí Pháp đương thời.

Các năm 1906, 1907 Nguyễn Tất Thành đang học tiểu học tại Huế đã học văn học Pháp, đã từng đọc với tất cả niềm say mê tác phẩm của Huygô, Dôla, Anatôn Franxơ... Sau này trong bài báo về Cách viết Hồ Chí Minh kể lại thời kỳ ở Pháp Người “có ý muốn là viết truyện ngắn". Rồi: "Dám viết thử, là vì có một hôm xem hai quyển truyện nhỏ, một quyển của Anatôn Phrăngxơ, một quyển nữa là của ông Tônxtôi. Xem thấy các ông ấy viết giản đơn lắm, dễ hiểu lắm”. ${ }^{12}$ Quyển truyện ngắn của Anatôn Phrăngxơ mà tác giả nói ở đây, rất có thể là truyện Trên đá trắng. Trong Nhũng mẩu chuyện về đời hoạt động của Hồ Chủ tịch,

${ }^{10}$ Hồ Chi Minh toàn tập (2011), Nxb Chính trị Quốc gia - Sự thật, tập1, tr 52 .

${ }^{11}$ Hồ Chí Minh toàn tập (2011), Nxb Chính trị Quốc gia - Sự thật, tập 1 , tr 156 .

${ }^{12}$ Hồ Chi Minh toàn tập (2011), Nxb Chính trị Quốc gia - Sự thật, tập 8, tr 211. chính tác giả đã khẳng định: "Anatôn Phơăngxơ (Anatole France) và Lêông Tônxtôi có thể nói là người đỡ đầu văn học cho ông Nguyễn". Trên tạp chí Nhân đạo năm 1904 có đăng truyện Trên đá trắng của Anatôn Franxơ. Với bút pháp viễn tưởng tác giả miêu tả cuộc sống của nhân dân lao động trong Liên bang các dân tộc châu Âu khi đang ở đỉnh cao của chủ nghĩa cộng sản năm 2270. Truyện Con nguời biết mùi hun khói của Nguyễn Ái Quốc có lẽ chịu ảnh hưởng Trên đá trắng khi miêu tả một viễn cảnh vào năm 1998 kỷ niệm 50 năm cách mạng thành công của một nước Cộng hoà liên bang ở châu Phi.

Trong Bài nói chuyện tại Đại hội lần thư III của Đoàn Thanh niên Lao động Việt Nam, Bác Hồ trích hai câu thơ của hai nhà thơ cộng sản Pháp và Nga để động viên, khích lệ thanh niên phấn đấu vươn lên xây dựng chủ nghĩa xã hội:

"Nhà thơ Pháp, đồng chí Vayăng Cutuyariê viết: “Chủ nghĩa cộng sản là mùa xuân của loài người”.

Nhà thơ Xôviết, đồng chí Maiacốpxki viết: "Chủ nghĩa cộng sản là tuổi trẻ của thế giới do những người trẻ tuổi xây dựng nên". ${ }^{13}$

Có lẽ từ hai câu nói này Hồ Chí Minh đã khái quát thành một quy luật biện chứng: "Một năm khởi đầu từ mùa xuân. Một đời khởi đầu từ tuổi trẻ. Tuổi trẻ là mùa xuân của xã hội”. ${ }^{14}$

Thời kỳ hoạt động ở Pháp, Nguyễn Ái Quốc rất quan tâm đến văn học đương đại Pháp. Tiểu phẩm phê bình văn học đầu tiên của Người in trên báo Le Paria, số 10, ngày 15-1-1923 có tên Nhũng người bản xú được ura chuộng (Indigènes à la mode). ${ }^{15}$ Rất đúng với quan niệm văn học phục vụ chính trị, là vũ khí đấu tranh chống lại cái ác, cái xấu, ở bài báo này tác giả dùng phê bình văn học vào mục đích mỉa mai chế giễu chính sách phản động của nhà cầm quyền thực dân và hạ bệ luôn thứ văn học đi theo thứ chính trị cơ hội, giả dối, lừa gạt nhân dân. Tác giả nhại một cốt truyện hư cấu của tiểu thuyết đăng báo qua cách tóm tắt, câu chuyện ấy có không gian: "Hội chợ Mácxây" và "phòng ngủ lộng lẫy"; có nhân vật: "một chàng An

\footnotetext{
${ }^{13}$ Hồ Chí Minh toàn tập (2011), Nxb Chính trị Quốc gia - Sự thật, tập 13, tr 89.

${ }^{14}$ Hồ Chí Minh toàn tập (2011), Nxb Chính trị Quốc gia - Sự thật, tập 4, tr 194.

${ }^{15}$ Hồ Chí Minh toàn tập (2011), Nxb Chính trị Quốc gia - Sự thật, tập $1, \operatorname{tr} 152$.
} 
Nam kia làm nghề kéo xe", "một bà đầm xinh đẹp", "người yêu bị cắm sừng của bà"; có kịch tính cao trào, có cởi nút, có cả lời bình luận mỉa của người kể: "Ôi! lương thiện vậy thay!”. Một cốt truyện khó tin vì nó ngược đời: bà đầm xinh đẹp yêu một anh xe An Nam, anh xe An Nam đánh gục một kẻ cắp vốn "là chàng công tử”...Nhại lại câu chuyện ấy để châm biếm giễu cợt sâu cay sự giả dối của thực chất về cái gọi là "Hội chợ Mácxây" chẳng qua cũng là một sự "ngược đời", chỉ là trò lừa bịp dư luận, đổi trắng thay đen, lộn sòng các giá trị...

Khi trở về phương Đông hoạt động Hồ Chí Minh vẫn theo dõi thường xuyên đời sống chính trị và văn học Pháp. Đầu những năm 40 của thế kỷ XX, bọn bồi bút của đế quốc thực dân luôn tìm cách bôi nhọ, xuyên tạc, vu cáo đường lối tiến bộ của các đảng cộng sản. Trong Báo cáo về tình hình các đảng phái trong nuớc đọc tại Đại hội các đoàn thể cách mạng Việt Nam ở nước ngoài họp tại Liễu Châu (Quảng Tây) tháng 31944, Hồ Chí Minh phê bình một vở kịch Pháp để vạch trần âm mưu bỉ ổi này: "Có một nhà văn Pháp viết một vở kịch, nhan đề là "Hạnh phúc gia đình". Vai chính trong vở kịch là một cặp vợ chồng mới cưới, cô dâu bị bệnh đau đầu, cô ả khăng khăng cho rằng mình bị cộng sản bỏ thuốc độc; và những chuyện như mèo nhảy làm vỡ đĩa bát trong bếp đến chuyện nướng bánh không chín, nấu súp không ngon, cô ả cũng đổ tội cho cộng sản cả!" 16

Một ví dụ tinh tế: ngay tại nước Pháp, một nước có tiếng là văn minh, văn học Pháp có tiếng là rực rỡ, nền chính trị Pháp có tiếng là dân chủ mà còn có những chuyện ngược đời như vở kịch kia, thì một nước như Việt Nam còn đang là thuộc địa Pháp thì những chuyện kẻ thù vu cáo, dựng truyện cho cộng sản là dễ hiểu. Thế là bản chất đểu giả của kẻ thù được phơi bày, nhân dân thì hiểu, những người cộng sản chân chính thì an tâm.

3. Hướng nghiên cứu ký hiệu học hiện đang được quan tâm trên thế giới nhờ nó đi sâu vào các biểu trưng - nơi tập trung, tích hợp cao nhất các lớp mã văn hóa. Với đối tượng nghiên cứu là các văn bản được Nguyễn Ái Quốc - Hồ Chí Minh viết dưới ánh sáng văn hóa Pháp, một nền văn hóa giàu có biểu trưng thì đi theo hướng ký hiệu học sẽ có nhiều hứa hẹn. Trong

${ }^{16}$ Hồ Chi Minh toàn tập (2011), Nxb Chính trị Quốc gia - Sự thật, tập 3, tr 491,492. văn hóa Pháp có biểu tượng "con quái vật", theo một số nhà nghiên cứu là sự ảnh hưởng từ Kinh Thánh "con quái vật tượng trưng cho những sức mạnh phi lý tính, nó có những đặc tính của cái vô hình thù của trạng thái hỗn mang, tối tăm, của vực thẳm. Như vậy, con quái vật hiện thân cho sự phi nền nếp, phi mực thước, nó gợi lại thời kỳ chưa xác lập được trật tự, kỷ cương", và "tượng trưng cho một hàm số tâm thần, cho trí tưởng bị kích động và lạc hướng, là nguồn gốc của những tình trạng hỗn loạn và bất hạnh...". ${ }^{17}$

Nguyễn Ái Quốc đã nói một cách bản chất nhất, đích đáng nhất về thực dân đế quốc khi dùng hình tượng quái vật: "Thế giới sẽ chỉ có nền hoà bình cuối cùng khi tất cả các dân tộc tự mình thoả thuận với nhau cùng tiêu diệt con quái vật đế quốc chủ nghĩa ở khắp mọi nơi mà họ gặp nó. Trong khi chờ đợi ngày đó, hiện nay họ còn là nạn nhân của con quái vật ấy, đòi hỏi một cách nghiêm khắc, nhân danh nguyên tắc của dân tộc được quyền tự quyết và họ rất xứng đáng để lưu ý tiếng nói của họ phải được lắng nghe với tình cảm đậm đà trong nhân dân các nước châu Âu và châu Mỹ”. ${ }^{18}$

"Người Bắc Phi sẽ biến khỏi mặt đất, nếu giai cấp vô sản giác ngộ không đến cứu họ khỏi nền "văn minh" quái vật". 19

Cũng có thể coi biểu tượng quái vật là một ẩn dụ chỉ chủ nghĩa thực dân đế quốc mang bản chất ăn cướp, ăn cắp, chỉ nền "văn minh" phản động, phản văn hóa. Từ hình tượng ẩn dụ này đã bật ra các ý nghĩa phê phán chủ nghĩa đế quốc về sự quái lạ, về tính chất phản động đi ngược lại quy luật phát triển, quy luật tiến bộ, về sự tàn bạo, dã man, phản nhân tính. Về sau này (1965) tác giả vẫn dùng biểu tượng ấy vào việc tố cáo chiến tranh: "Trong những vùng ruộng lúa mênh mông bát ngát có các xóm làng. Giữa những đám nhà tranh, nổi lên những nhà máy ngói đỏ xinh đẹp, cây cối xanh tươi bao bọc xung quanh. Đó là một cảnh tượng hoà bình. Bất thình lình, con quái vật chiến tranh lù ra...". 20

Dưới cái nhìn của tác giả thì biểu trưng công lý của thực dân Pháp đồng nghĩa với hình tượng kẻ giết người:

\footnotetext{
${ }^{17}$ Jean Chevalier Alain Gheerbrant (2002), Tù điển biểu tuợng văn hoá thế giới, Nxb Đà Nẵng.

${ }^{18}$ Hồ Chi Minh toàn tập (2011), Nxb Chính trị Quốc gia - Sự thật, tập1, tr 17.

${ }^{19}$ Hồ Chí Minh toàn tập (2011), Nxb Chính trị Quốc gia - Sự thật, tập 1, tr 280.

${ }^{20}$ Hồ Chí Minh toàn tập (2011), Nxb Chính trị Quốc gia - Sự thật, tập 14, tr 654
} 
“Công lý được tượng trưng qua hình ảnh một nữ thần tay cầm cân và tay cầm kiếm. Nhưng Đông Dương lại ở quá xa nước Pháp, muôn trùng cách trở, nên khi nữ thần tới xứ này thì cán cân đã mất thăng bằng, đĩa cân đã chảy lỏng và biến thành những tẩu thuốc phiện và những chai rượu ty. Trên tay nữ thần tội nghiệp ấy chỉ còn độc cái kiếm để chém giết. Bà đã chém những người vô tội và cũng chỉ chém có họ mà thôi!". ${ }^{21}$

“Trong khi hãy còn bị xích cổ, thế mà con hổ chẳng đã nhá nghiến mất nhiều bộ của nước Cộng hoà đó sao? Người ta chẳng đã phí hàng mấy triệu, mấy tỷ để nhờ hai ông bạn vinh quang của chúng ta là Contrắc và Vranghen mua hộ da con gấu Mátxcơva, là con vật ngày nay hơn bao giờ hết, nó không thích để cho người ta tuỳ ý muốn làm gì thì làm đó sao?...

Trong số các bạn hữu ở chính quốc của chúng ta, ai là người không phải phàn nàn về tai hại do loài diều hâu gây ra? Loài quạ mà lại chẳng phải là những kẻ phá hoại tai hại trong địa hạt tinh thần à? Còn những con mọt già thì có làm được việc gì ngoài cái việc chỉ chuyên tìm cách lợi dụng những sự bất hoà và những chuyện xích mích trong xã hội?... Bọn mèo quý phái há chẳng thật sự là những kẻ đã dập tắt cả hạnh phúc gia đình của nhiều nhà đó? Và những con chuột cống ở khách sạn chẳng đã là những kẻ thù muôn thuở của tất cả những người đi du lịch đó sao?”.22

Trên đây là đoạn trích trong Bộ suru tập động vật (Ménagerie) in trên Le Paria, số 11 ngày 1/2/1923. Đối chiếu với những sự kiện chính trị được nói bóng gió trong bài chúng ta hiểu sâu hơn ý nghĩa các biểu tượng. Con hổ ám chỉ Clêmăngxô (1841-1929), vốn là một bác sỹ rồi tham gia chính trị, là một nghị sỹ cấp tiến trong quốc hội Pháp, phái cực tả, từng làm Bộ trưởng Chiến tranh, năm 1920 thất bại trong cuộc tranh cử Tổng thống nước Pháp. Loài quạ chỉ những kẻ viết thư nặc danh, nhũng con mọt già (bản phiên âm: Chats-fourrés nghĩa đen chỉ những con mèo lông xù), ở đây được dùng theo nghĩa bóng chỉ bọn quan toà; bọn mèo quý phái (poules de luxe) chỉ gái điếm hạng sang; nhũng con chuột cống ở khách sạn (Rats d'hôtel) chỉ bọn chuyên trộm cắp hành lý của khách trọ. Những ẩn dụ ám chỉ ấy đã khơi gợi ở người đọc sự tìm tòi, suy ngẫm, liên tưởng. Càng ngẫm kỹ càng

${ }^{21}$ Hồ Chí Minh toàn tập (2011), Nxb Chính trị Quốc gia - Sự thật, tập 1 , tr 51 .

${ }^{22}$ Hồ Chí Minh toàn tập (2011), Nxb Chính trị Quốc gia - Sự thật, tập 1, tr 160 . thấy cái tinh tế thâm thuý, châm biếm nhẹ nhàng mà sắc lẻm vào từng đối tượng.

Những tác phẩm (truyện ngắn, tiểu luận, bài báo...) được Nguyễn Ái Quốc viết bằng tiếng Pháp đăng trên báo Pháp dành cho đối tượng đọc là người Pháp và những người biết tiếng Pháp, do vậy phải viết theo phong cách văn hóa Pháp, mà cách dùng các biểu tượng là một biểu hiện. Tác giả hay dùng lối ngụ ngôn, một thể loại được ưa chuộng ở Pháp, do đặc trưng có xu hướng triết lý về đạo lý, giáo huấn, giáo dục nên hình tượng luôn vươn đến tầm khái quát biểu tượng. Có thể coi Bộ sưu tập động vật là một ngụ ngôn trào phúng hiện đại mang ý nghĩa luận tội, kết án chính sách bóc lột của các nước thực dân, đế quốc ở các thuộc địa:

"Người ta thường quên, tưởng rằng các nhà bảo hộ của chúng ta lúc nào cũng thi hành cái chính sách của loài đà điểu". ${ }^{23}$ Đà điểu là một loài chim lớn sống ở miền nhiệt đới châu Phi có dạ dày rất khỏe, "chính sách của loài đà điểu" (Politique de l'autruche) là một ẩn dụ mỉa tố cáo chính sách vơ vét tham lam vô độ của chủ nghĩa thực dân. Vẫn trong tiểu phẩm này có các biểu tượng: “Cái con chó ngắn mõm chẳng đã chạy đến nhe bộ răng khả ố của nó ra mà xé toạc cả cơ cấu của Hội nghị Pari đó sao? Thành thử con khỉ phlamăng và con gà trống gôloa phải một mình đương đầu với con phượng hoàng giécmanh ở miền Ruya". Sau Chiến tranh 1(1914-1918) các đế quốc tham gia chiến tranh họp Hội nghị Vécxây để phân chia lại quyền lợi và bàn cách tăng cường bóc lột thuộc địa. “Con chó ngắn mõm” ám chỉ nước Anh, "con khỉ phlamăng” ám chỉ nước Bỉ, "gà sống gôloa" - nước Pháp, “con phượng hoàng giecmanh" - nước Đức. Cách dùng ẩn dụ trào phúng đã làm nổi lên bản chất ăn cướp và những mâu thuẫn quyền lợi không thể dung hòa của chủ nghĩa đế quốc.

Trên báo Le Paria số 2 ngày 1/5/1922 đăng bài Động vật học mỉa mai thói nhu nhược nô lệ có chi tiết "Nó đi hai chân. Nhưng, theo tài liệu quan sát được tại những vùng châu Á, thì nhiều khi nó lại được coi như loài bốn chân". Chi tiết này được chính tác giả chú thích về "loài bốn chân" là "loài quan lại trong tư thế Xalamalếch”. Xalamalếch có nguồn gốc từ ngôn ngữ

\footnotetext{
${ }^{23}$ Hò̀ Chí Minh toàn tập (2011), Nxb Chính trị Quốc gia - Sự thật, tập1, tr 162.
} 
Ả Rập dùng để chào hỏi với nghĩa Chúc an lành. Tiếng Pháp mượn từ này để chỉ lối chào quá cầu kỳ, kiểu cách, đơn điệu, lặp lại. Đến lượt Nguyễn Ái Quốc mượn lại để mỉa mai lối chào quỳ gối, rạp mình, chống tay chẳng khác gì "loài bốn chân", cũng là những kẻ chấp nhận sống kiếp "động vật" cam chịu làm nô lệ cho kẻ xâm lược.

Trong tiểu phẩm Tập đoàn kẻ cướp mượn lời nhân vật là nhà thám hiểm Pháp, ông Combane nói theo lối "vạch áo cho người xem lưng" về bản chất bóc lột của thực dân Pháp và thảm cảnh diệt vong của xứ Đông Dương nô lệ: "Nói về các món độc quyền, người ta có thể hình dung Đông Dương nhu một con nai béo đẹp bị trói chặt tàn nhẫn và đang hấp hối dưới những cái mỏ quắm của bầy diều hâu rỉa móc mãi không biết chán". ${ }^{24}$

Lời của ông này được "bảo hiểm" bởi hai lý do: ông Combane người Pháp (chứ không phải người Đông Dương) nên nói đúng về sự thật người Pháp bóc lột thậm tệ xứ Đông Dương. Ông lại là nhà "thám hiểm" đi đó đây nhiều, chứng kiến nhiều nơi có những chế độ chính trị khác nhau nên có con mắt đối sánh, do vậy sự nhận xét mang tính bản chất. Những tư cách ấy cho phép ông dùng những hình tượng đậm tính biểu trưng là hợp lý: "bầy diều hâu", theo nghĩa đen là loài chim ăn thịt, tinh ranh, gợi ở người đọc suy nghĩ về sự tham lam, tàn nhẫn trong việc bóc lột, đục khoét, vơ vét của chủ nghĩa tư bản đối với người dân bản xứ. Một hình ảnh tác động mạnh vào thị giác người đọc: "một con nai béo đẹp bị trói chặt tàn nhẫn". Con nai vốn đã hiền lành, nhút nhát lại còn bị trói chặt thì càng không có cách gì tự cứu mình, đành chịu "hấp hối dưới những cái mỏ quắm của bầy diều hâu rỉa móc mãi không biết chán". Ý nghĩa phổ quát của hình tượng đã vượt lên trên giá trị tự thân để vươn tới tầm thời đại: báo động khẩn cấp về sự diệt vong bởi chủ nghĩa thực dân trên xứ Đông Dương không thể tự vệ, không ai bênh vực, và càng không biết tự cứu mình!

Hồ Chí Minh hiểu sâu sắc ngôn từ biểu trưng của giới quý tộc Pháp. Một lần Hội đồng Chính phủ họp để trao Huân chương cho Bác sỹ Tôn Thất Tùng, Người nói: "Chú Tùng là một Xidovan mà nay được

${ }^{24}$ Hồ Chi Minh toàn tập (2011), Nxb Chính trị Quốc gia - Sự thật, tập 1, tr 401 .
Chính phủ ta tặng Huân chương. Chú phải cố gắng hơn nữa!". 25

Từ Cidovant là danh từ mà Cách mạng Pháp 1789 dành cho các nhà quý tộc tài năng. Dùng từ này với nhiều ẩn ý: Một là rất kính trọng tài năng, nhân cách của "Chú Tùng"; hai là "Chú Tùng" đã từng là "một nhà quý tộc" Pháp, có công với nước Pháp, nay được Chính phủ ta tặng Huân chương, có nghĩa là Chính phủ rất biết trọng dụng nhân tài, dù người tài đó đã từng phục vụ nước Pháp; Ba là, mong muốn "Chú Tùng" thật đúng như "một Xidovan", một Xidovan của cách mạng Việt Nam!

Cây đại thụ văn hóa Hồ Chí Minh cường tráng lực lưỡng nhiều cành lá tươi mới, sum suê là nhờ bộ rễ rất khỏe có ba nhánh cắm rất sâu vào ba mảnh đất văn hóa: văn hóa dân tộc Việt, văn hóa phương Đông, văn hóa phương Tây (trong đó văn hóa Pháp là rất quan trọng, cơ bản). Nhờ nắm vững, hiểu sâu ngôn ngữ, văn học, văn hóa Pháp tác giả mới có thể viết được những tác phẩm mang chất Pháp mà lại mang nội dung mới, nội dung chống lại chủ nghĩa thực dân, đế quốc để đòi giành lại độc lập tự do cho các thuộc địa, cho những con người bị mất tự do trên toàn thế giới. Tiếp thu, học tập, kế thừa tinh hoa văn học Pháp đã góp phần tạo ra một phong cách văn chương Hồ Chí Minh đa dạng, độc đáo, đặc sắc, tinh tế.

\section{TÀI LIỆU THAM KHẢO}

1. Hồ Chí Minh toàn tập (2011), Nxb Chính trị Quốc gia - Sự thật, 17 tập;

2. Nhiều tác giả (2010), Hồ Chí Minh với văn nghệ sỹ, văn nghệ sỹ với Hồ Chí Minh, Nxb Hội Nhà văn, 10 tập;

3. Nguyễn Thanh Tú (2017), Ngôn ngũ và tu tuởng, Ngôn ngữ học Việt Nam 30 năm đổi mới và phát triển (Kỷ yếu Hội thảo khoa học Quốc tế), Nxb Khoa học xã hội, tr 681-699.

\footnotetext{
${ }^{25}$ GS. Trần Văn Giàu (2010), Hồ Chí Minh vĩ đại một con người, Nxb Chính trị Quốc gia, tr 758.
} 


\section{Nguyen Ai Quoc - Ho Chi Minh and French literature}

Nguyen Thanh Tu, Dinh Thanh Huong

\section{Article info}

Recieved:

06/5/2018

Accepted:

$12 / 6 / 2018$

Keywords:

culture, folklore, written literature, symbols.

\begin{abstract}
This article proves Ho Chi Minh learning from French literature in three aspects: Folklore, written literature, French cultural symbols. It follows, that, the quintessences of French literature has contributed to the literary style of Ho Chi Minh, which is very unique, distinct and refined. This is a standard for today: first of all, one must have love for his country, for his people, so that he can acquire thoroughly and most usefully the foreign culture.
\end{abstract}

